\title{
Isolating the 'Pure' Effect of the 2004/2005 Bank Consolidation Policy on Performance of Banks in Nigeria, Using the Chow Test (2000-2010)
}

\author{
Ibrahim Gerarh Umaru ${ }^{1}$ \\ ${ }^{1}$ Department of Economics, Nasarawa State University, P.M.B. 1022, Keffi-Nigeria \\ Correspondence: Ibrahim Gerarh Umaru, Department of Economics, Nasarawa State University, P.M.B. 1022, \\ Keffi-Nigeria. E-mail: umaru8@gmail.com
}

Received: August 16, 2013

Accepted: September 16, 2013

Online Published: September 25, 2013

doi:10.5430/afr.v2n4p47

URL: http://dx.doi.org/10.5430/afr.v2n4p47

\begin{abstract}
A cursory review of existing impact study literature of 2004/2005 Nigerian bank consolidation, of which mergers and acquisitions were the main policy thrust, revealed that most studies concluded that the policy has had a tractable and significant impact on bank intermediation, deposits mobilization and management of loans and advances as well as bank performance. However, a critical analysis of the literature showed that majority of existing studies were neither founded on a sound theoretical premise nor their models sophisticated enough to distil the 'real' licy from the superficial and added-up effect of pooling capital bases, deposits, credit balances and book profits of several banks. To overcome the observed shortcomings, full estimated generalized least-square (FEGLS) and fixed effect-least-squares dummy variable (LSDV) models were developed. A panel data consisting of 11-year time series data, covering six stratified randomly selected consolidated banks in Nigeria was used in the study. While FEGLS was designed to isolate the 'pure' impact of the policy on bank performance using the Chow test procedure, the LSDV model was deployed to test the hypothesis that the overall impact was not evenly spread across banks. The results of the empirical estimation seem to cast doubt on the validity of the general conclusion of past studies - that the policy has had 'real' and significant impact on bank intermediation, portfolio management and performance. The study observed that this conclusion probably due to the short-term nature of the period covered by most of the studies and recommended the use robust methodologies by subsequent research on the subject.
\end{abstract}

Keywords: Bank consolidation, Intermediation, Chow test, Mergers and acquisitions, Nigeria

\section{Introduction}

As part of the overall banking reform intended to foster a comprehensive and healthy financial system to support economic development and avoid systemic distress, the Central Bank of Nigeria (CBN) in July 2004 directed all banks to shore up their minimum paid up capital from two to 25 billion of Naira before the end of December 2005. In particular, banks were encouraged to explore all possible options, including merger and acquisition. By the end of the exercise, the number of banks in operation reduced from 89 to just 25 .

Eight years after, another round of banking reforms is well under way. As expressed in the Financial System Strategy 2020 (FSS2020), this reform is intended to not only consolidate the gains of the previous reform but to reposition the sector to a play a leading role in repositioning Nigeria as one of the top twenty economies in the world by the year 2020. However, the question is what are these gains that the new reform purports to build upon? Has the 2004/2005 bank reform recorded any meaningful impact on bank operation especially in terms of bank efficiency, shareholders' wealth and the real sector of the economy, in the first place?

Indeed, there have been a number of attempts to provide an answer to this question in the past few years. For instance, one official assessment of the Nigerian monetary authorities asserted that the reforms had changed the activities of the financial sector for good and impacted positively on the economy in several ways (Sanusi, 2012). However, on the other hand, there is a minority of studies as shall be shown shortly, which tends to conclude that the impact of the banking reform, especially M\&A has been negligible or nil. It is therefore the objective of this paper to critically examine these arguments, their methodologies and inner logic with the aim of identifying the 'real' effect of the reform on bank performance. 
The remainder of this paper is divided into five sections. The next section undertakes a critical review of existing empirical literature on the subject. It is also intended to identify gaps in the literature and provide a synthetic framework of developing a model that will have the capacity to technically isolate the 'pure' effect of 2004/2005 merger and acquisition on bank performance. Section three outlines the methodology used in the study. It is sub-divided into four parts namely, 'model specification'; 'population of the study and survey sample'; and 'nature and sources of data'. The empirical results are then presented in section four, while section five forms the concluding remark segment of paper.

\section{Literature Review}

A healthy and strong economy depends on a sound, stable, robust, and modern financial system (Joshua, 2011). This explains why the Nigerian banking sector has undergone several episodes of reform aimed at repositioning it, and reintegrating same into the regional and global financial systems (Akpan, 2007). Perhaps the most far-reaching reform ever undertaken in Nigeria's recent past was the 2004 Bank Consolidation Policy. Merger and acquisition were two of the options opened to operators in the industry to consider in a bid to shore up their capital base to the minimum set by the 2004 CBN Bank Consolidation directive (Soludo, 2004).

Merger can be defined as a transaction where one entity is combined with another, so that the first or second entity loses its distinct identity. Acquisition is often defined as a transaction where one firm purchases a controlling stake (and/or the whole) of another firm (Pandey, 2008; Mangold and Lippok, 2008; Afolabi, 2011). Theoretically speaking, mergers and acquisitions (M\&A) are undertaken for a number of reasons, which include costs saving, income enhancement and shareholders pressure at the firm-level; government deregulation and improvement in technology at the country or global level (Afolabi, 2011).

Following the implementation of the bank consolidation policy, attempts have been made to evaluate the impact of M\&A on the overall soundness of the industry, competition and growth, banks' performance. To find out if Nigeria's banking sector has benefitted from consolidation through reduced costs and improved competition, Barros and Caporale (2012) developed a generalized method of moments (GMM) model. Using dynamic panel data for the period $2000-2010$, they found that the sector has benefitted from the consolidation process and specifically that foreign ownership, mergers and acquisitions and bank size decreased costs. In a similar study, Okafor et al. (2012) sought to examine the changing nature of competition during and immediately after the consolidation within the context of Nigeria's banking sector reform. The results they obtained seem to support the official position that M\&A in the banking industry had promoted sustained competition and higher efficiency levels, resulting in a minimal reduction of interest rate spread. While the approach adopted by Okafor et al. (2012) was robust, utilizing the strengths of the Herfindahl-Hirscman index, the model developed by Barros and Caporale (2012) had the capacity of allowing for dynamics in the dependent variable because of the inbuilt and plausible empirical assumption that the best performing banks were likely to remain so in the subsequently years. However, the two models were not specifically developed to estimate the impacts of M\&A on the selected banks' operating/financial performance, as their main focus was on the bigger picture - competition and efficiency.

On bank soundness, Ebimobowei and Sophia (2011) challenged the efficiency of the wave of M\&A that took place in the Nigerian banking sector within the study period, while Ernest (2012) explored the marketing implication of M\&A in the Nigerian banking sector. As the former made no attempt to use an objective or statistical method to substantiate their claims, the latter's analysis was largely subjective, giving little or no objective basis to authenticate their claims.

Saibu (2013) developed a cross-section random effects (EGLC) model to examine the impact of bank consolidation on financial intermediation using data from Nigeria's banking industry from 2002 to 2010. Quite true, the author was able to establish a cause-effect relationship between key macroeconomic financial variables, but he failed to shed light on the relationship between M\&A and bank performance, especially at the microscopic level of analysis.

One of the topical issues that cropped up in the debate preceding the implementation of the bank consolidation as well as the years after, was the question of whether the policy would ever lead to growth in the industry. To examine the appropriateness of M\&A as a bail-out solution to corporate financial stress, Akilubi and Kelilume (2013) conducted a survey covering six banks, including leaders in the industry. Using simple statistical methods and partial ratio analysis, they demonstrated that M\&A are not a prima facie solution to the problem of financial distress in corporate organizations, especially in the Nigerian banking industry. They argued that this is particularly so when M\&A were imposed by regulatory authorities instead of allowing the business environment to drive the process. Their study further revealed that while M\&A can drive growth and profitability in some organizations, operating efficiency suffers at least in the short-term in the post-M\&A corporate entity. 
Quite a number of studies have been carried out on the effect of bank consolidation policy on the operational performance of banks in Nigeria. Elumilade (2010) attempted to verify the gains that have been credited to M\&A on banks in Nigeria, especially on financial intermediation, by reconciling data with reality. Using a simple regression analysis involving interest rate, bank deposits and other financial variables, he showed that the consolidation programme-induced M\&A in the banking industry had improved competitiveness and efficiency of borrowing and lending operations in the Nigerian banking industry. However, aside from the fact that the model building and explanation were not rigorous enough, the full regression results were not fully disclosed. Similarly, Awolusi (2012) examined the impact of M\&A on perceived business performance measures (PBPM). Combining regression analysis with a survey technique which covered 19 banks, the author's interpretation seemed to confirm that M\&A had significant impact on business performance of bank within the study period. However, this study suffered from the same shortcomings as Elumilade (2010).

Asuquo (2012) also attempted to trace the effects of bank consolidation reforms on small business lending activity in Nigeria. To do that, he developed a simple linear regression model and utilized panel data to show that bank size, financial characteristics and deposits of non-merged banks were positively related to small business lending while for the merged banks, the reverse was the case. However, the trouble with his analysis was that the method of sampling used was not random. It is highly suspected that by that because of this bias, distortions might have been introduced that could have unduly influenced his results. More fundamentally however, the bivariate model used by the author was too primitive to have captured the complex channels the impact of M\&A would have filtered onto the performance of the banks covered in the survey. Lastly, a closer look at the results revealed that the presence of autocorrelation would have led the author to delineate a wider confidence interval for the standard errors of estimated coefficients, thereby vitiating the validity of the conclusion reached.

Adebayo and Olalekan (2012) assessed the implication of M\&A of commercial banks in Nigeria on their profitability and other associated measures of performance. Using $t$-test and correlation coefficient analysis, they analyzed the data from the audited accounts of 10 out of the 24 consolidated banks. The results of their analysis revealed that there was a significant relationship between banks' capital base and their profitability, increased cost of services and bank lending. Also, Dele (2012) investigated the relationship between what he termed 'critical factors' and customer service management following M\&A in Nigeria. The author claimed he used structural equation modeling approach and utilized primary data for his study. However, nowhere in the body of his article was the statistical expression of the building blocks of the system of equations given nor the structure of the model shown.

Umoren and Olokoyo (2007) examined the impact of M\&A on the performance of banks within the pre- and the post-consolidation periods. In particular, the focus of the study was on liquidity and solvency. A performance ratio analysis of a sample of 13 mega banks was carried out. The authors found that, on the average, bank consolidation resulted in improved performance. However, the use of simple ratios and descriptive statistics did not allow the study to control for intervening factors, thereby making it impossible to isolate the 'pure' impacts of M\&A on bank performance. Similar results were obtained by Adegboyega (2012) after evaluating the impact of M\&A on the performance of two consolidated banks. Though he was able to split the impact into their respective pre- and post-consolidation parts, the author was unable to control for intervening variables, making his findings spurious and conclusions superfluous.

Maimako and Oladele (2012) evaluated the impact of bank restructuring on the creation of shareholders' value. The study combined survey with secondary data in a descriptive statistical analysis to arrive at its conclusion: M\&A and capital restructuring had significant impacts on value creation, though capital restructuring exerted greater influence. This study suffers from the shortcoming of being unable to provide a platform for isolating the 'pure' effect of M\&A on bank performance, as well. In a similar vein, Okpara (2011) and Joshua (2011) used accounting ratios and simple statistical analysis ( $t$-test) to trace the impact of M\&A on bank performance in Nigeria. However, their analyses were not rigorous enough to evaluate the impact of the M\&A on either the operational performance or financial performance of the banks.

Technically speaking, the most far-reaching study that tried to split the impact of M\&A on performance banks into their pre- and post-consolidation components, conduct a comparative analysis of the two and isolate the 'pure' effect of M\&A on banks' performance was Omah et al. (2013). The authors reviewed the extant literature and observed that post-M\&A studies follow either of the following two approaches or a combination of both: improvement in performance; or shareholders value analysis. They also observed that studies on M\&A in Nigeria, especially those conducted before 2012, were quite few. Besides, most of them stopped at comparing pre- and post-M\&A performance using a case-by-case approach or general description of M\&A and their accounting framework. An 
added value of the study was that it covered all the consolidated/merged banks. Equally, a noticeable improvement of the study over existing literature was its ability to assess inter-company performance. In addition, the use of value added metrics to convert conventional ratios into more statistically meaningful variables was the hallmark of the study.

In spite of all these, the authors did not explicitly tell how the results of the two-period regressions would be interpreted or which statistical procedure was used to compare differences in the results. As a matter of fact, the authors failed to develop a statistical measure or procedure to control for intervening variables and isolate the 'pure' effect of M\&A on profitability and shareholders' wealth.

Recognizing these shortcomings and developing tractable models that will explicitly control for intervening factors, and be used empirically to isolate the 'pure' impact of M\&A on banks' performance between 2000 and 2010 was the motivation behind this study. To accomplish this task, three hypotheses were set for the study. The first hypothesis was formulated to validate the general finding of most studies previously reviewed which indicated that bank consolidation through M\&A had significantly impact on financial intermediation as reflected in bank portfolio (deposits, loans and advances) management in Nigeria between 2005 and 2010. The aim for setting the second hypothesis was to find out if M\&A did improve the overall bank performance within the study period. The third hypothesis attempted to confirm if any observed improvement in the overall bank performance was evenly distributed. Two empirical models were developed as frameworks to test these hypotheses.

\section{Methodology}

\subsection{Model Specification}

The banking sector is an important component of the Nigerian economy (Olaloku, 1984; Kwanashie, 1989; Anyanwu et al., 1997). Its importance springs from the fact that it serves as a lubricant to economic activity in the real sector of the economy. It plays the role of mobilizer, storekeeper and manager of financial resources; or an intermediator between networth individuals with excess or idle balances (often referred to as surplus spending units, SSUs) and those economic agents who are always in need of such resources for consumption or production - deficit spending units, DSUs - (Umole, 1985). The act of bridging the gap between income receipts and expenditure, or what is referred to as financial intermediation, is what banks are best known for.

The business of banks involves primarily the acceptance of deposits from individuals and organizations; and the use of these resources for lending to investors and individuals in the economy in the form of loans and advances (Anyanwu, 1993). Banks in Nigeria are regarded as business organizations, recognized as individuals or economic entities in the Nigerian Companies and Allied Matters Act 1990 (CAMA) as well as in the Banks and Other Financial Institutions Decree (BOFID). These laws empower shareholders to raise and upscale their authorized capital, distribute and retain profits earned. Whether viewed from the point of view of the agency theory or that of the stakeholders' theory, CAMA and BOFID allow banks duly registered in Nigeria to either set profit maximization as their goal or the maximization of their shareholders' wealth. Accordingly, two indicators often used to measure the movement in bank's profitability and shareholders wealth are return on equity (ROE) and return on assets (ROA) (Akinsulire, 2002; Omah et al., 2013).

Aside from the fact that banks are going concerns and driven by the value-enhancement objective, be it profit or shareholders' wealth, their central role as providers of a payment system and facilitators of value creation, monetary authorities often ascribe to the banking sector an important strategic responsibility in the macroeconomic management of the country (CBN). This explains the episodic changes in banking policy in Nigeria, of which the CBN 2004 directive on M\&A to Nigerian bank consolidation of was an instance. We model this essential relationship schematically in Figure 1. As the figure depicts, such policy changes are expected to impact positively on the economy through healthy competition and growth in the industry, enhanced performance as well as improved social responsibility of banks. 


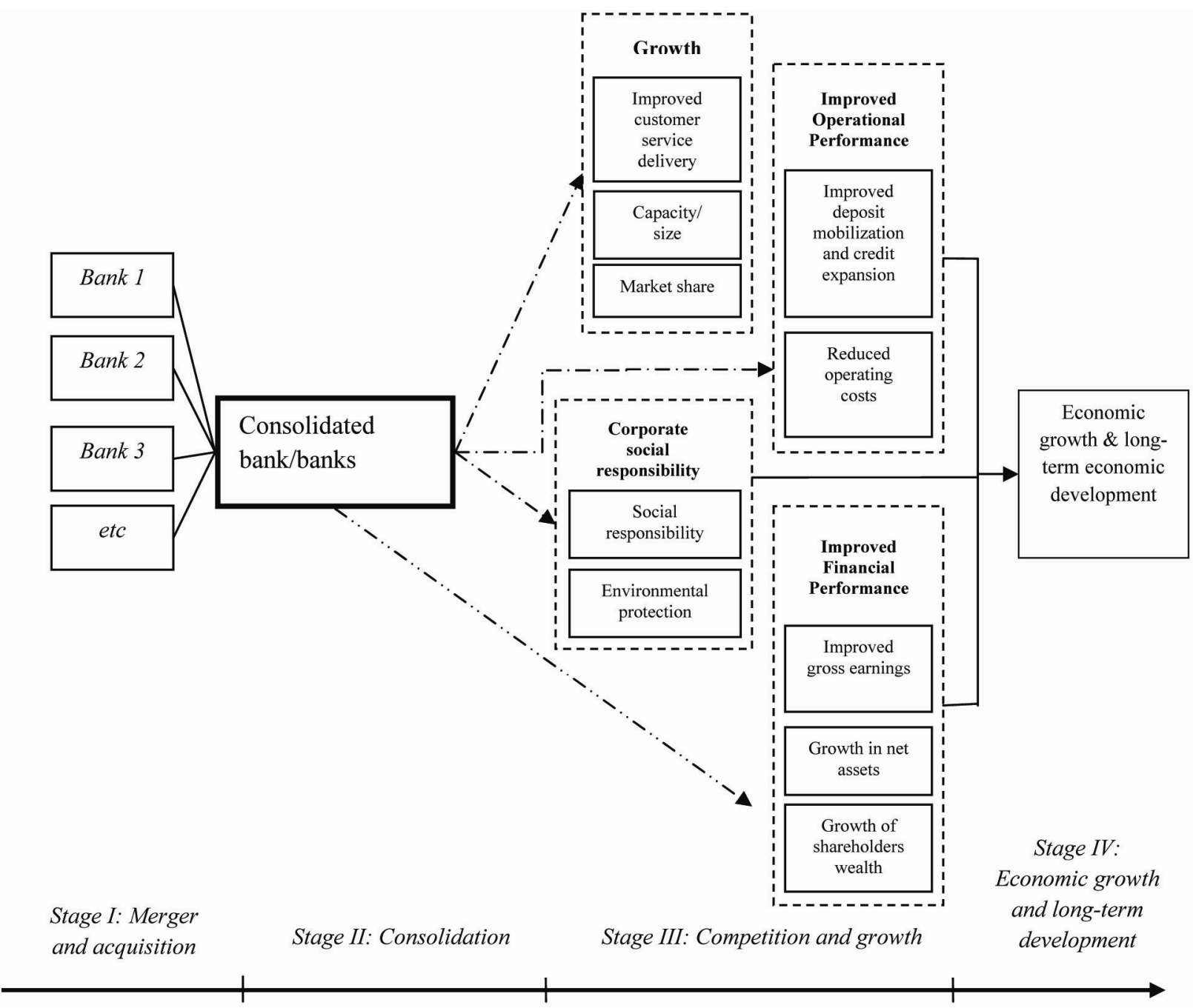

Figure 1. A schematic depiction of the relationship between merger and acquisition and bank performance

Banking theory and experience globally show that M\&A have the potential to improve the performance of consolidated companies by way of injecting fresh managerial expertise, pooling of financial and other resources, taking advantage of already established intangibles, shoring up of shareholders fund, winning costumers' loyalty through improvement in the company's market value on the stock exchange, and so on. All these were some of the reasons advanced by the CBN for implementing the 2004/2005 bank consolidation policy. It is therefore hypothesized in this discourse that bank's financial performance $\left(P_{\text {Bank }}\right)$ is a positive function of M\&A. However, the performance of a bank may equally be influenced by other important variables such as bank deposits growth $\left(D E P_{\mathrm{Mob}}\right)$, bank loans or credit expansion $\left(L O A N_{\mathrm{Gr}}\right)$, and government regulations $\left(G O V_{\mathrm{Reg}}\right)$ executed through the $\mathrm{CBN}$ routine/ad hoc directives and guidelines. Symbolically,

$$
P_{\text {Bank }}=f\left(M \& A, \mathrm{DEP}_{\mathrm{Mob}}, \mathrm{LOAN}_{\mathrm{Gr}}, \mathrm{GOV}_{\mathrm{Reg}}\right)
$$

The problem with some of the variables in (1) is that they are not directly measurable, especially $P_{\text {Bank }}, M \& A$, and $G O V_{\text {Reg. }}$. However, the good news is that we can use some other variables or proxies to quantify them. For instance, we have already noted that two accounting indicators often used to measure financial performance are $R O A$ and $R O E$. Similarly, we can use capitalization or recapitalization to measure the impact of M\&A in a company or bank over time, but especially insofar as Nigeria's CBN banks' consolidation policy is concerned. This is so because the ultimate goal of the policy on M\&A in the Nigerian banking industry was to encourage banks to shore up their capital base or capitalization ( $\mathrm{Cap}$ ). Government regulations as variables are usually not easy to quantify due to their qualitative nature. However, because government regulations influence bank performance in a complex way, but through the instrumentality of CBN's routine directives and mechanisms involving capitalization, bank deposits and loans and advances and borrowing by investors, the impact of government regulations is subsumed under the 
relationship between $P_{\mathrm{Bank}}$, Cap, $D E P_{\mathrm{Mob}}$ and $L O A N_{\mathrm{Gr}}$. A non-linear specification of eq. (1) would have been a preferred option for this study, but for the fact that data on the variables would be converted into ratios or decimals. Because of this, the explicit version of eq. (1) is constrained to take a linear form:

$$
P_{\text {Bank }_{i t}}=\alpha_{i t}+\beta_{1}(\mathrm{Cap})_{i t}+\beta_{2}\left(\mathrm{DEP}_{\mathrm{Mob}}\right)_{i t}+\beta_{3}\left(\mathrm{LOAN}_{\mathrm{Gr}}\right)_{i t}+u_{i t}
$$

where

$$
\left[\left(\frac{\partial P_{\text {Bank }}}{\partial C a p}\right)>0 ;\left(\frac{\partial P_{\text {Bank }}}{\partial D E P_{\text {Mob }}}\right)>0 ;\left(\frac{\partial P_{\text {Bank }}}{\partial L O A N_{G r}}\right)>0\right] ; P_{\text {Bank }_{i t}}=R O E_{\text {Bank }_{i t}} \text { or } R O A_{\text {Bank }_{i t}} ;
$$

$i=$ selected bank; and $t=$ time represented by year.

One interesting advantage of the specification expressed in equation (2) is that, the effect of $M \& A$ proxied by Cap on $P_{\text {Bank }}$ as proxied by $R O E$ and $R O A$ can be tracked by concentrating on the coefficient $\left(\beta_{1}\right)$ attached to the variable, Cap.

An alternative specification is to, initially split the study period into two - the first being the pre-consolidation period consisting of 6 years $(2000-2005)$, and the post-consolidation period consisting of 5 years $(2006-2010)$. This situation is akin to having three possible regressions:

$$
\begin{aligned}
& \text { Time period 2000-2005[ } \left.n_{1}=6\right]: P_{\text {Bank }_{i t}}=\varphi_{i t}+\lambda_{1}(\text { Cap })_{i t}+\lambda_{2}\left(\mathrm{DEP}_{\mathrm{Mgt}}\right)_{i t}+\lambda_{3}\left(\mathrm{LOAN}_{\mathrm{Mgt}}\right)_{i t}+\varepsilon_{i t} \\
& \text { Time period 2000-2005[ } \left.\mathrm{n}_{2}=5\right]: P_{\text {Bank }_{i t}}=\theta_{i t}+\gamma_{1}(\text { Cap })_{i t}+\gamma_{2}\left(\mathrm{DEP}_{\mathrm{Mgt}}\right)_{i t}+\gamma_{3}\left(\mathrm{LOAN}_{\mathrm{Mgt}}\right)_{i t}+\zeta_{i t} \\
& \text { Time period 2000-2005[ } \left.\mathrm{n}_{3}=11\right]: P_{\text {Bank }_{i t}}=\alpha_{i t}+\beta_{1}(\mathrm{Cap})_{i t}+\beta_{2}\left(\mathrm{DEP}_{\mathrm{Mgt}}\right)_{i t}+\beta_{3}\left(\mathrm{LOAN}_{\mathrm{Mgt}}\right)_{i t}+u_{i t}
\end{aligned}
$$

If eq. (5) were to be regressed, it would be interpreted as if there were no difference between the first two time periods, and therefore the relationship between Cap, DEP, LOAN and $P_{\text {Bank, }}$, consisting of data on selected for 11 years. In other words, this regression assumes that the intercept as well as the slope coefficient remains the same over the entire period. If this were in fact the case, then $\varphi_{i t}=\vartheta_{i t}=\alpha_{i t} ; \lambda_{1}=\lambda_{2}=\lambda_{3} ;$ and $\gamma_{1}=\gamma_{2}=\gamma_{3}$.

Regressions (4) and (5) assume that the regressions in the two time periods are different - the intercept and slope coefficients are different. In the preceding regressions, $\varepsilon_{i t}, \zeta_{i t}$ and $u_{i t}$ represent the error terms and $n$ 's represent the number of observations.

In practice, it is usually the tradition to apply the Chow procedure in order to isolate the 'pure' effect of each regressor (in this case, Cap, $D E P$ and $L O A N$ ) on the regressand (in this particular case, $P_{\text {Bank }}$ ). The mechanics of the Chow test are as follows (Gujarati and Porter (2009): 1) estimate regression eq. (5), which is appropriate if there is no parameter instability, and obtain its residual sum of squares $\left(R S S_{3}\right)$ with $\left(n_{1}+n_{2}-k\right)$ degrees of freedom, where $k$ is the number of parameters estimated, and call it the 'restricted residual sum of squares' $\left(R S S_{\mathrm{R}}\right)$ because it is obtained by imposing the restrictions $\lambda_{1}=\lambda_{2}=\lambda_{3}$; and $\gamma_{1}=\gamma_{2}=\gamma_{3}$.2) Estimate eq. (3) and obtain its residual sum of squares, $R S S_{1}$, with $\left(n_{1}-k\right)$ degrees of freedom. 3) Estimate eq. (2) and obtain its residual sum of squares, $R S S_{2}$, with $\left(n_{2}-k\right)$. 4) Since the two sets of samples are assumed independent, $R S S_{1}$ and $R S S_{2}$ should be added to obtain what could be referred to as the 'unrestricted residual sum of squares' $\left(R S S_{\mathrm{UR}}\right)$, that is, $R S S_{U R}=R S S_{1}+R S S_{2}$ with $\left(\mathrm{n}_{1}+n_{2}-2 k\right)$ degrees of freedom. The Chow test assumes that the error terms $\left(\varepsilon_{i t}\right.$ and $\left.\zeta_{i t}\right)$ in the sub-period regressions are normally distributed with the same (homoscedastic) variance; and that the two error terms are independently distributed.

The idea behind the Chow test is that if in fact there is no structural change [in our case, no difference in bank performance between the pre- and post-consolidation periods, that is between eq.'s (3) and (4)], then the $R S S_{\mathrm{R}}$ and $R S S_{\text {UR }}$ should not be statistically different. Chow (1960) has shown that under the null hypothesis which states that there is no statistical difference between eq.'s (3) and (4), the $F$ ratio given below follows the $F$ distribution with $k$ and $\left(n_{1}+n_{2}-2 k\right)$ degrees of freedom in the numerator and denominator, respectively:

$$
F=\frac{\left(R S S_{R}-R S S_{U R}\right) / k}{\left(R S S_{U R}\right) /\left(n_{1}+n_{2}-2 k\right)} \sim F_{\left[k,\left(n_{1}+n_{2}-2 k\right)\right]}
$$

The decision rule would then be to conclude that M\&A via Cap or $D E P$ or $L O A N$ had impacted significantly on $P_{\text {Bank, }}$ if computed $F$ value exceeds the critical $F$ value; otherwise we state the contrary.

Much as the model specification expressed in eq.'s (2), (3), (4) and (5) can be used to filter out the influence of other variables and in isolating the 'pure' and overall effect of $M \& A$, as proxied by capitalization variable, Cap, on banks' 
performance, it can hardly segregate and estimate the magnitude of that overall impact (if there was any) for each sampled bank. To 'empower' the model to perform this twin role, there is the need to transform equation (5) to a 'fixed effect-least-squares dummy variable ( $L S D V$ ) model. This model allows for heterogeneity among subjects (in this case, banks) by allowing each entity to have its own intercept value. The term, 'fixed intercept', is due to the fact that, although the intercept may differ across subjects (banks in this case), each entity's intercept does not vary over time. To allow for the fixed effect intercept to vary among banks, the differential intercept dummy technique can be used to transform eq. (5) to a $L S D V$ model shown in eq. (7).

$$
P_{\text {Bank }_{i t}}=\alpha_{1}+\alpha_{j} \sum_{j=1}^{n} D_{j . i j}+\beta_{1}(\text { Cap })_{i t}+\beta_{2}\left(\mathrm{DEP}_{\mathrm{Mgt}}\right)_{i t}+\beta_{3}\left(\operatorname{LOAN}_{\mathrm{Mgt}}\right)_{i t}+u_{i t}
$$

Where $D_{1 . i j}=1$ for bank 2, 0 otherwise; $D_{2 . i j}=1$ for bank 3, 0 otherwise; $D_{j . i j}=1$ for bank 4, and 0 otherwise; and so on. The first bank is treated as the base. The intercept $\alpha_{1}$ is the value of the base bank and the other first bank is treated as the base with the intercept $\alpha$ coefficients representing by how the intercept values of the other banks differ from the intercept value of the base bank. Thus, first bank is treated as the base with the intercept $\alpha_{2}$ tells by how much the intercept value of the second bank differs from first bank is treated as the base with the intercept $\alpha_{1}$. The sum $\left(\alpha_{1}+\alpha_{2}\right)$ gives the actual value of the intercept for bank 2 . The intercept values of the other banks can be computed similarly. To make eq. (7) statistically tenable we make the assumption that the error variance is the same for all cross-section units; after all, the banks to be included in the survey are coming from the same population (Gujarati and Porter, 2009).

\subsection{Population of the Study and Survey Sample}

The population of this study comprises all the 21 consolidated merged deposit money banks quoted on the Nigerian Stock Exchange as at 2010. To determine the appropriate sample size for the study as well as select the sample elements, giving each equal chance of being selected, the stratified random sampling technique was used. First, Yamane (1973) was used to determine the sample size for the study:

$$
s=\frac{N}{3+N(M E)^{2}}=\frac{21}{3+21(0.0025)}=\frac{21}{3.0525} \approx 6
$$

Where $s=$ desired sample size; $N=$ survey population; and $M E=$ margin of error allowable. Given the survey population as 21, and providing for a 5 per cent margin of error, a sample size of 6 (approximated) was adopted for the study.

A random sampling procedure (utilizing the random table as a guide) was then used to select six banks from the list of 21 consolidated banks. Before the six banks were selected, the 21 banks were categorized into three strata (high, medium and low) using the size of their capital base as yardstick. The six banks penciled were First Bank, United Bank for Africa (UBA), Access Bank, Diamond Bank, Guaranty Trust (GT) Bank and First City Monument Bank $(F C M B)$.

\subsection{Nature and Sources of Data}

Two performance indicators were used as proxies to measure bank performance namely $R O E$ and $R O A$. To measure the two, the broad scope performance metric paradigm of economic value added was adopted. Thus, $R O E$ was initially calculated as net operating profits after taxes but before interest, less cost of capital employed; while ROA was computed as profit after tax divided by net assets. For analytical brevity, absolute values of $R O E$ and $R O A$ were converted into relative values using the formula, $R R O E=[(R O E / C E) \times 100]$ and $R R O A=[(R O A /$ Net Assets $) \times 100]$, where $\mathrm{CE}=$ capital employed. The impact of $M \& A$ was proxied by the variable $C a p$ and measured as annual authorized and fully paid-up capital. The impact of bank's deposit mobilization was proxied by the movement in bank's annual deposits, while bank's credit growth is proxied by the movement in bank total loans and advances.

For this study, time series data for the period 2000- 2010 (11 years) were pooled across six banks (First, UBA, Access, Diamond, $G T$ and $F C M B$ ) initially. Then to allow for the 'pure' effect to be isolated, the panel was split into two periods, the pre-consolidation $(2000-2005)$ and the post-consolidation $(2006-2010)$. Data were collected from the annual reports of the selected banks, $C B N$ and the Nigerian Stock Exchange reports.

\section{Analysis of Estimation Results}

Equations (3), (4) and (5) were estimated using ordinary least-squares $(O L S)$ procedure, the results of which are presented in Table 1. Both for the bank performance indicators, $R O A$ and $R O E$, and for pre-, post-consolidation and pooled regressions, the goodness-of-fit $\left(R^{2}\right)$ statistics were reasonably high, implying that there was a strong 
statistical relationship between capitalization, loans and advances and bank performance within the study period. However, the results exhibited traces of positive serial/spatial correlation, judging from the values of the Durbin-Watson (D.-W.) statistics for all the regressions.

Table 1. OLS estimation results of pre-, post-consolidation and pooled regressions

\begin{tabular}{|c|c|c|c|c|c|c|c|c|}
\hline \multirow[b]{2}{*}{ Variable } & \multicolumn{4}{|c|}{ RETURN ON ASSETS (ROA) } & \multicolumn{4}{|c|}{ RETURN ON EQUITY (ROE) } \\
\hline & Coefficient & $\begin{array}{l}\text { Standard } \\
\text { error }\end{array}$ & $t$-value & $\rho$-value & Coefficient & $\begin{array}{l}\text { Standard } \\
\text { error }\end{array}$ & $t$-value & $\rho$-value \\
\hline \multicolumn{9}{|c|}{ Pre-consolidation (2000-2005) } \\
\hline Constant & $0.0906^{*}$ & 0.0212 & 4.2750 & 0.0002 & $0.2314^{*}$ & 0.0348 & 6.6435 & 0.0000 \\
\hline Capitalization & -0.0932 & 0.1029 & -0.9054 & 0.3720 & -0.2166 & 0.1691 & -1.2807 & 0.2095 \\
\hline Loans and Advances & -0.0135 & 0.0104 & -1.2100 & 0.2029 & $0.0262 *$ & 0.0171 & 1.5294 & 0.1360 \\
\hline Deposits & 27.6693 & 20.6487 & 1.3400 & 0.1897 & -54.6912 & 33.9264 & -1.6121 & 0.1168 \\
\hline$R^{2}$ & 0.7278 & & & & 0.7451 & & & \\
\hline$R S S$ & 0.1754 & & & & 0.4730 & & & \\
\hline$D-W$. statistic & 1.3269 & & & & 1.5837 & & & \\
\hline \multicolumn{9}{|c|}{ Post-consolidation (2006-2010) } \\
\hline Constant & $0.0969 *$ & 0.0191 & 5.0755 & 0.000 & 0.1323 & 0.0220 & 6.0017 & 0.0000 \\
\hline Capitalization & $-0.1590 * *$ & 0.0875 & -1.8171 & 0.0807 & -0.0837 & 0.1011 & -0.828 & 0.4150 \\
\hline Loans and Advances & -0.0007 & 0.0023 & -0.2853 & 0.7777 & $-0.0060 *$ & 0.0027 & -2.2199 & 0.0354 \\
\hline Deposits & -1.4799 & 3.4723 & -0.4262 & 0.6735 & $6.9670 * *$ & 4.0102 & 1.7373 & 0.0942 \\
\hline$R^{2}$ & 0.5453 & & & & 0.6058 & & & \\
\hline$R S S$ & 0.1401 & & & & 0.1869 & & & \\
\hline$D-W$. statistic & 0.8419 & & & & 1.9706 & & & \\
\hline \multicolumn{9}{|l|}{ Pooled (2000-2010) } \\
\hline Constant & $0.0969 *$ & 0.0135 & 7.1524 & 0.000 & $0.2314^{*}$ & 0.0348 & 6.6435 & 0.0000 \\
\hline Capitalization & $-0.1527 *$ & 0.0634 & -2.409 & 0.019 & -0.2166 & 0.1691 & -1.2807 & 0.2095 \\
\hline Loans and Advances & 0.0005 & 0.0018 & 0.3030 & 0.763 & 0.0262 & 0.0171 & 1.5294 & 0.1360 \\
\hline Deposits & -0.7263 & 3.3753 & -0.2152 & 0.830 & -54.691 & 33.926 & -1.6121 & 0.1168 \\
\hline Goodness of fit $\left(R^{2}\right)$ & 0.8786 & & & & 0.7451 & & & \\
\hline$R S S$ & 0.3335 & & & & 0.4730 & & & \\
\hline$D-W$. statistic & 1.0366 & & & & 1.5837 & & & \\
\hline
\end{tabular}

* significant at 5 per cent level

** significant at 10 per cent level

Park (1966) test for heteroscedasticity was also conducted. The results of the test are shown in Table 2. As Park (1966) and Harvey (1976) suggest, it was concluded that while the variable representing capitalization exhibited traces of heteroscedasticity as shown by its p-value, loans and advances did not.

Table 2. Results for the Park test for Heteroscedasticity

\begin{tabular}{lllll}
\hline Variable & Coefficient & $\boldsymbol{t}$-value & p-value \\
\hline PRE-CONSOLIDATION PERIOD & & \\
Capitalization & $-4.4769^{*}$ & -16.9860 & 0.0075 \\
Loans and Advances & -0.03277 & -2.7663 & 0.4763 \\
Deposits & 76.6547 & 0.8894 & 0.3772 \\
\hline POST-CONSOLIDATION PERIOD & \\
Capitalization & 1.32684 & 0.63379 & 0.5307 \\
Loans and Advances & 0.096968 & 0.4586 & 0.6500 \\
Deposits & -286.3542 & -0.6819 & 0.5002 \\
\hline POOLED PERIOD & & & \\
Capitalization & -0.8707 & -0.3025 & 0.7647 \\
Loans and Advances & -0.02128 & -0.2716 & 0.7881 \\
Deposits & -74.1669 & -0.6348 & 0.5311 \\
\hline
\end{tabular}

* significant at 5 per cent level

Similarly, a simple $R$-squared test of multcollinearity was conducted on the three regressions. The results of the test are displayed in Table 3. It can easily be seen that while the three regressions exhibit reasonably high $R$-squared's, few corresponding $t$-values of their coefficients were statistical significant, suggesting the presence of 
multicolliniearity. This was further confirmed by the collinearity analysis carried out which showed a high pair-wise correlation among the regressors.

Table 3. $R$-squared test results for multicollinearity

\begin{tabular}{|c|c|c|c|c|c|c|c|c|}
\hline \multicolumn{5}{|c|}{ RETURN ON ASSETS (ROA) } & \multicolumn{4}{|c|}{ RETURN ON EQUITY (ROE) } \\
\hline Equation & $R$-squared & Variable & $t$-value & $p$-value & $R$-squared & Variable & $t$-value & $p$-value \\
\hline \multirow[t]{4}{*}{ Pre-consolidation } & & Capitalization & -0.9054 & 0.3720 & \multirow{4}{*}{0.7451} & Capitalization & -1.2807 & 0.2095 \\
\hline & 0.7278 & Loans and & & & & Loans and & & \\
\hline & & advances & -1.2999 & 0.2029 & & advances & 1.5294 & 0.1360 \\
\hline & & Deposits & 1.3400 & 0.1897 & & Deposits & -1.6121 & 0.1168 \\
\hline \multirow[t]{5}{*}{ Post-consolidation } & & Capitalization & $-1.8171^{*}$ & 0.0807 & \multirow{4}{*}{0.6058} & Capitalization & -0.8284 & 0.4150 \\
\hline & 0.5453 & Loans and & & & & Loans and & & \\
\hline & & advances & -0.2853 & 0.7777 & & advances & -2.2199 & 0.0354 \\
\hline & & Deposits & -0.4262 & 0.6735 & & Deposits & $1.73730 * *$ & 0.0942 \\
\hline & & Capitalization & $-2.4089 *$ & 0.0190 & \multirow{4}{*}{0.7451} & Capitalization & -1.2807 & 0.2095 \\
\hline \multirow[t]{3}{*}{ Pooled } & 0.8386 & Loans and & & & & Loans and & & \\
\hline & & advances & 0.3030 & 0.7629 & & advances & 1.5294 & 0.1360 \\
\hline & & Deposits & -0.2152 & 0.8303 & & Deposits & -1.6121 & 0.1168 \\
\hline
\end{tabular}

* significant at 5 per cent level

** significant at 10 per cent level.

In order to go round the above observed statistical shortcomings and thus improve on the predictive power of the empirical models, variables equations (3) and (4) (and by extension (5)) were transformed using the Prais-Winsten transformation method suggested by Davidson and MacKinnon (1993); then applying the full estimated generalized least-square $(F E G L S)$ procedure. The final results are shown in Table 4.

Table 4. Full estimated generalized least squares (FEGLS) results of pre-, post-consolidation and pooled regressions after adjusting for

\begin{tabular}{|c|c|c|c|c|c|c|c|c|}
\hline \multirow[b]{2}{*}{ Variable } & \multicolumn{4}{|c|}{ RETURN ON ASSETS (ROA) } & \multicolumn{4}{|c|}{ RETURN ON EQUITY (ROE) } \\
\hline & Coefficient & $\begin{array}{l}\text { Standard } \\
\text { error }\end{array}$ & $t$-value & $\rho$-value & Coefficient & $\begin{array}{l}\text { Standard } \\
\text { error }\end{array}$ & $t$-value & $\rho$-value \\
\hline \multicolumn{9}{|c|}{ Pre-consolidation (2000-2005) } \\
\hline Constant & $0.0465^{\dagger}$ & 0.0153 & 3.0287 & 0.005 & $0.1129^{\dagger}$ & 0.0314 & 3.5917 & 0.0011 \\
\hline Capitalization & 0.0226 & 0.0900 & 0.2509 & 0.804 & 0.0564 & 0.1843 & 0.3058 & 0.7617 \\
\hline Loans and Advances & $-0.0181^{\dagger}$ & 0.0086 & -2.0971 & 0.044 & 0.0185 & 0.0177 & 1.0459 & 0.3034 \\
\hline Deposits & $35.9045^{\dagger \dagger}$ & 18.0866 & 1.9852 & 0.056 & -32.4711 & 37.0413 & -0.877 & 0.3872 \\
\hline$R^{2}$ & 0.8326 & & & & 0.8563 & & & \\
\hline$R S S$ & 0.1293 & & & & 0.5424 & & & \\
\hline$D-W . \quad$ statistic & 1.945 & & & & 1.8945 & & & \\
\hline \multicolumn{9}{|c|}{ Post-consolidation (2006-2010) } \\
\hline Constant & $0.0413^{\dagger}$ & 0.0174 & 2.3729 & 0.0253 & $0.1476^{\dagger}$ & 0.0327 & 4.5166 & 0.0001 \\
\hline Capitalization & 0.0588 & 0.1188 & 0.4950 & 0.6247 & -0.2216 & 0.2228 & -0.994 & 0.3292 \\
\hline Loans and Advances & -0.0135 & 0.0092 & -1.4632 & 0.1554 & 0.0167 & 0.0173 & 0.9695 & 0.3413 \\
\hline Deposits & 25.5115 & 19.2702 & 1.3239 & 0.1971 & -26.4037 & 36.143 & -0.731 & 0.4716 \\
\hline$R^{2}$ & 0.7778 & & & & 0.7864 & & & \\
\hline$R S S$ & 0.1929 & & & & 0.3845 & & & \\
\hline$D-W . \quad$ statistic & 1.8637 & & & & 1.7576 & & & \\
\hline \multicolumn{9}{|l|}{ Pooled (2000-2010) } \\
\hline Constant & $0.0358^{\dagger}$ & 0.0084 & 4.2569 & 0.0001 & $0.0681^{\dagger}$ & 0.0154 & 4.4225 & 0.0000 \\
\hline Capitalization & -0.0904 & 0.0612 & -1.4766 & 0.1448 & -0.0963 & 0.1120 & -0.860 & 0.3933 \\
\hline Loans and Advances & 0.0010 & 0.0015 & 0.63367 & 0.5286 & $-0.0056^{\dagger t}$ & 0.0028 & -1.997 & 0.0503 \\
\hline Deposits & -3.0968 & 2.5980 & -1.1920 & 0.2378 & $10.4547^{\dagger}$ & 4.7534 & 2.1994 & 0.0316 \\
\hline$R^{2}$ & 0.8902 & & & & 0.9026 & & & \\
\hline$R S S$ & 0.1979 & & & & 0.6624 & & & \\
\hline$D-W . \quad$ statistic & 2.059 & & & & 2.0560 & & & \\
\hline
\end{tabular}

\footnotetext{
${ }^{\prime}$ significant at 5 per cent level
}

"t significant at 10 per cent level. 
Table 4 also shows that the overall predictive power of the model, measured by the $R$-squared statistic, was enhanced by the Prais-Winsten transformation and the use of the FEGLS procedure. The $R$-squared statistics of $R O E$ for the three periods appreciated: $15 \%$ (pre-consolidation); $30 \%$ (post-consolidation); and $21 \%$ (pooled). Similarly, the $R$-squared statistics of $R O A$ for the pre-consolidation regression rose from 0.5453 to 0.8326 ; from 0.5453 to 0.7778 for the post-consolidation; and from 0.87860 .8902 for the pooled regression.

For residual sum of squares (RSS), the situation was somewhat different as it turned out to be a mixture of improvement and deterioration. RSS is simply an indication of how much the estimated regression deviates from its true population. From Table 4, it is obvious that for the ROA indicator, $R S S$ deteriorated by $26 \%$ and rose by $38 \%$ for pre-consolidation and post-consolidation regressions, respectively, due to variable transformation and improvement in the estimation procedure. However when the pooled regression is considered, there seems to be an overall improvement of $41 \%$ in $R S S$. The situation was somewhat different with the ROE indicator. The RSS statistic for pre-and post-consolidation, as well as pooled regression deteriorated by $15 \%, 106 \%$ and $40 \%$, respectively.

As indicated previously, three hypotheses were set for testing in this study. The first hypothesis was formulated to authenticate the general finding of most studies reviewed which alluded M\&A as having impacted significantly on bank intermediation, especially on bank portfolio management in the post-consolidation period. To do this we concentrate on the second part of Table 4 which shows the results of post-consolidation regression. For the ROA performance indicator, except for $L O A N_{\mathrm{GR}}$, all the coefficients had the correct signs. For the $R O E$ indicator, the reverse was the case - only $L O A N_{\mathrm{GR}}$ had the correct sign. Judging by the magnitude (size) of their coefficients, it would appear bank performance in the post-consolidation period was better explained by growth in deposit base (than in the capital base) in the ROA model; while in the ROE model, it was growth in loans and advances. However, when subjected to the statistical test of significance, none of the coefficient turned out to be significant either at $5 \%$ or $10 \%$ level. The implication of all these is that, the validity of the assertion that M\&A had significantly impacted on bank intermediation and portfolio management between 2005 and 2010 appears suspicious.

The second hypothesis states that M\&A did not improve the overall performance of the consolidated banks in the post-consolidation period. To test this hypothesis, a Chow test was performed on the reported RSS statistics and degrees of freedom in Table 5, using the $F$-distribution test of equation (6).

Table 5. RSS values and degrees of freedom used in the Chow test

\begin{tabular}{|c|c|c|}
\hline \multirow[b]{2}{*}{ VARIABLE } & \multicolumn{2}{|l|}{ COEFFICIENT } \\
\hline & $\begin{array}{l}\text { RETURN ON ASSETS } \\
\text { (ROA) }\end{array}$ & $\begin{array}{l}\text { RETURN ON EQUITY } \\
\text { (ROE) }\end{array}$ \\
\hline$R S S_{\text {pre }}$ & 0.1293 & 0.5424 \\
\hline$R S S_{\text {post }}$ & 0.1929 & 0.3845 \\
\hline$R S S_{U R}$ & 0.3222 & 0.9269 \\
\hline$R S S_{R}$ & 0.1979 & 0.6624 \\
\hline$n_{1}$ & 36 & \\
\hline$n_{2}$ & 30 & \\
\hline$k$ & 3 & \\
\hline
\end{tabular}

$$
\begin{gathered}
F_{c}(R O A)=\frac{(0.1979-0.3222) / 3}{0.3222 /(72)}=-9.248 \\
F_{c}(R O E)=\frac{(0.6624-0.9269) / 3}{(0.9269) /(72)}=-6.849 \\
\mathrm{~F}_{\mathrm{T}}(0.05)=2.25
\end{gathered}
$$


The test results show that while the computed $F$-value for $R O A$ was -9.248 , that of ROE was -6.849 . Both were lower than the $5 \%$ critical value of 2.25 and $10 \%$ value of 1.87 . To authenticate the validity of using the Chow test, its underlying assumption - that there no difference between error terms of eq.'s (3) and (4) - was also subjected to the $F$-test. At $5 \%$ level, the calculated $F$-values for ROA and ROE were 1.823 and 0.866 , respectively, which were both lower than the critical value of 1.89; implying that for both $R O A$ and $R O E$, the Chow test was valid.

Based on all of these results, it was therefore concluded that the null hypothesis of no difference between bank performance between the pre-consolidation and post-consolidation periods should not be rejected; implying that the thesis emanating from previous studies that the overall performance of banks had been enhanced due to M\&A in Nigeria may not be true.

The aim of the third hypothesis was to disaggregate the overall impact of M\&A on bank performance (if there was any) and see if the gains of the policy were evenly spread among the selected banks. However, on the strength of the outcome of the first two hypotheses, which statistically showed that M\&A did not impact significantly on the post-consolidation performance of banks in Nigeria (at least within the study period), test of the third hypothesis was unnecessary.

\section{Concluding Remarks}

Before concluding, it would be instructive to acknowledge the time and spatial limitations of the study. Out of a total number of 21 as at 2010, only six banks were included in the study. Although it is true that the statistical method used in sample selection allows for six could be adjudged sufficient for an analysis with a population of 21, caution should however be exercised in using the findings of this study to generalize for the entire banking sector in Nigeria. It is indeed not quite impossible to have arrived at a different conclusion, were the whole 21 banks considered in the impact analysis.

Also, it could be argued that the overall conclusion of this study which seems to have indicated that the 'pure' effect of M\&A on post-consolidation bank performance was insignificant, may not have come as too much a surprise. This is because, the time span of the analysis (2005-2006) could be considered not reasonable long enough for the real effect of the policy to have manifested in improved bank intermediation, better portfolio management and improved performance. Perhaps, what most past studies had reported as 'significant impacts' were simply the manifest, nominal and immediate (short-term) effect of aggregations of hitherto individual bank's capital bases, deposits, loans and advances and book profits, rather than qualitative increases in efficiencies and growth rates in capitalization, deposit mobilization, management of loans and advances and their value added contribution to bank performance in Nigeria. Certainly, all these would require enough time, change in bank strategy and investment in manpower training and skill and technology. This can only be achieved in the long-run. Lastly, it is recommended that subsequent studies on the subject should separate the long-term 'pure' effect of the reform bank performance from the short-run impacts using an appropriate methodology such as the one adopted in this study or a more robust approach.

\section{References}

Adebayo, O., \& Olalekan, O. (2012). An analysis of the impact of mergers and acquisitions on commercial banks performance in Nigeria. Research Journal of Finance and Accounting 3(7): 91-101.

Adegboyega, O.I. (2012). Mergers and acquisitions and bank performance in Nigeria. JORIND 10(2): 338-347.

Afolabi, J.A. (2011). Mergers and acquisitions in the Nigerian banking system: Issues and challenges. Paper presented at the Workshop for Business Editors and Finance Correspondents Association of Nigeria held at Manpower Development Institute, Dutse, Jigawa State.

Akilubi, S.F., \& Kelilume, I. (2013). The effects of mergers and acquisition on corporate growth and profitability: evidence from Nigeria. Global Journal of Business Research 7(1): 43-58.

Akinsulire, O. (2002). Financial management ( $\left.2^{\text {nd }} E d\right)$. Lagos: Ceemol.

Akpan, A.B. (2007). Effectiveness of bank capitalization and consolidation in building market confidence: An assessment of customer perception in Nigeria. Abuja Journal of Business Administration 1(2): 23-45.

Anyanwu, J.C. (1993). Monetary economics: Theory, policy and institutions. Onitsha: Hybrid Publishers.

Anyanwu, J.C., Oyefusi, A., OIkhenan, H. \& Dimowo, F.A. (1997). The structure of the Nigerian economy (1960-1997). Onitsha: Joanee Educational Publishers. 
Awolusi, O.D. (2012). The effect of mergers and acquisitions on business performance in Nigerian banking industry: An empirical analysis. International Journal of Business Performance Management 13(3/4): 366-385.

Asuquo, A.I. (2012). Empirical analysis of mergers and acquisitions on small business lending in Nigeria. International Journal of Advancements in Research and Technology 1(6): 1-15.

Barros, C.P. \& Caporale, G.M. (2012). Banking consolidation in Nigeria, 2000-2010.

Economics and finance working paper series 12-06, Department of Economics and Finance, Brunel University, London.

Chow, G.C. (1960). Tests of equality between sets of coefficients in two linear regressions. Econometrica 28(3): 591-605. http://dx.doi.org/10.2307/1910133

Davidson, R., \& MacKinnon, J.G. (1993). Estimation and inference in econometrics. New York: Oxford University Press.

Dele, A.O. (2012). Empirical assessment of mergers and acquisition on customer service management in the Nigerian banking industry. Universal Journal of Marketing and Business Research 1(4): 112-122.

Ebimobowei, A., \& Sophia, J.M. (2011). Mergers and acquisition in the Nigeria banking industry: An explorative investigation. Social Sciences 6(3): 213-220.

Elumilade, D.O. (2010). Mergers and acquisitions and efficiency of financial intermediation in Nigeria: An empirical investigation. International Journal of Business and Management 5(5): 201-210.

Ernest, I.E. (2012). Bank consolidation in Nigeria: Marketing implications and challenges for surviving banks. Arts and Social Science Journal 2012(ASSJ 31):1-14.

Gujarait, D.N., \& Porter, D.C. (2009). Basic Econometrics $5^{\text {th }}$ edition. Boston: McGraw Hill.

Harvey, A.C. (1976). Estimating regression models with multiplicative heteroscedasticity. Econometrica 44(3): 461-465. http://dx.doi.org/10.2307/1913974

Joshua, A. (2011). Comparative analysis of the impact of mergers and acquisitions on financial efficiency of banks in Nigeria. Journal of Accounting and Taxation 3(1): 1-6.

Kwanashie, M. (1989). Commerce and banking. In: Kayode, M.O., \& Usman, Y.B. (Eds), Nigeria since independence: The first 25 years Vol. II (the economy). Ibadan: Heinemann Educational Books (Nigeria).

Maimako, S.D., \& Oladele, K.O. (2012). Impact of corporate restructuring on value creation in the Nigerian Banking Industry. SDMIMD Journal of Management 1(1): 12-21.

Mangold, N.R., \& Lippok, K. (2008). The effect of cross-border mergers and acquisitions shareholder wealth. Journal of International Business and Economics 5(8): 12-19. Retrieved 21 July, 2013 from: http://Www.Britannica.Com/Bps/Additionalcontent/18/35637611/The-Effect-of-Crossborder-Mergers-and-Acq uisitions-on-Shareholder-Wealth-Evidence-from-Germany.

Okafor, C., Russell, K., \& Lawal, L. (2012). Effects of the Nigerian banking consolidation on competition. In: Menyak, K. and Joshua, A. (Ed.) Finance and Development in Africa (Research in Accounting in Emerging Economies), Volume 12. London: Emerald Group Publishing.

Okpara, G.C. (2011). Bank reforms and the performance of the Nigerian banking sector: An empirical analysis. International Journal of Current Research 2(1): 142-153.

Olaloku, F.A . (1984). Monetary system and policy. In Olaloku, F.A., Fajana, F.O.

Tomori, S. \& Fapohunda, E.R. (Eds.). Structure of the Nigerian economy. London/Lagos: Macmillan Publishers and The University of Lagos Press.

Omah, I., Okolie, J.U., \& Durowoju, S.T. (2013). Mergers and acquisitions: Effects on shareholders' value evidence from Nigeria. International Journal of Humanities and Social Science 3(6): 151-159.

Pandey, I.M. (2008). Financial Management $9^{\text {th }}$ edition. New Delhi: Vikas.

Park, R.E. (1966). Estimation with heteroscedastic error terms. Econometrica 34(4): 884- 889. http://dx.doi.org/10.2307/1910108 
Saibu, M.O. (2013). The impact of mergers and acquisition on financial intermediation: Evidence from Nigerian banking industry. Ersa South Africa: Economic Research Papers. Retrieved 21 July, 2013 from: http://www.econrsa.org/system/files/workshops/papers/2013/saibu.pdf.

Sanusi, S.L. (2012). Banking reforms and its impacts on Nigeria economy. Lecture delivered at the University of Warwick's Economic Summit, Warwick 17 February, 2012.

Soludo, C.C. (2004). Consolidating the Nigerian banking industry to meet the development challenges of the $21^{\text {st }}$ century. Address delivered to the special meeting of the Bankers' Committee held on July 6, 2004 at the Central Bank Headquarters.

Umole, J.A. (1985). Monetary and banking systems in Nigeria. Zaria: Gaskiya Corporation.

Umoren, A.O. \& Olokoyo, F.O. (2007). Merger and acquisition in Nigeria: Analysis of performance pre- and postconsolidation. Lagos Journal of Banking, Finance and Economic Issues 1(1): 1-16.

Yamane, T. (1973). Statistics: An introductory analysis. New York: Harper and Row. 